\title{
Socioeconomic conditions on poverty levels a case study: Central Java Province and Yogyakarta in 2016
}

\author{
Condições socioeconômicas sobre os níveis de pobreza, um estudo de caso: \\ províncias de Java Central e Yogyakarta em 2016
}

Achmad Tjachja Nugraha1 (D), Gunawan Prayitno² (D), Listio Nandhiko³ (D), Ahmad Riswan Nasution ${ }^{4}$ (1)

${ }^{1}$ Socio-Economy and Agriculture (Agribusiness) Department, Universitas Islam Negeri Syarif Hidayatullah (UIN), Jakarta, Indonesia. E-mail: achmad.tjachja@uinjkt.ac.id

${ }^{2}$ Urban and Regional Planning Department, Universitas Brawijaya (UB), Malang, Indonesia. E-mail: gunawan_p@ub.ac.id

${ }^{3}$ Badan Pusat Statistik (BPS), Provinsi Maluku, Indonesia. E-mail: nandhikolistio@gmail.com

${ }^{4}$ The Center of Education and Training of Badan Pusat Satistik (BPS), Jakarta, Indonesia. E-mail: ahmadriswan73@gmail.com

How to cite: Nugraha, A. T., Prayitno, G., Nandhiko, L., \& Nasution, A. R. (2022). Socioeconomic conditions on poverty levels a case study: Central Java Province and Yogyakarta in 2016. Revista de Economia e Sociologia Rural, 60(1), e233206.

https://doi.org/10.1590/1806-9479.2021.233206

\begin{abstract}
This study aims to analyze how the influence of infrastructure availability, socioeconomic conditions, and the effect of location on poverty levels. The descriptive analysis is used to give a general description of poverty by using thematic charts and maps. The poverty map is analyzed by spatial autocorrelation of poverty levels by using a Moran Scatterplot and the Local Indicators of Spatial Association (LISA) Map. The results of the study indicate the existence of spatial linkages to poverty. The Increasing of other variables outside the model in neighboring regions will increase the level of poverty in a region. The infrastructures of road extension, clean water infrastructure, economic growth, quality of education, and health have a significant influence on the level of poverty, while the percentage of satisfactory sanitation did not demonstrate to affect the significant effect on poverty. The conclusion is that the level of poverty in the provinces of Central Java and Yogyakarta has an irregular distribution and a clustered spatial pattern.
\end{abstract}

Keywords: level of poverty, spatial model, spatial regression analysis.

Resumo: Este estudo tem como objetivo analisar como a disponibilidade de infraestrutura, as condições socioeconômicas e o efeito da localização influenciam nos níveis de pobreza. A análise descritiva é usada para dar uma descrição geral da pobreza usando cartas e mapas temáticos. O mapa da pobreza é analisado por autocorrelação espacial dos níveis de pobreza, pelo uso de um gráfico de dispersão de Moran e do Mapa de Indicadores Locais de Associação Espacial (LISA). Os resultados do estudo indicam a existência de ligações espaciais à pobreza. O aumento de outras variáveis fora do modelo em regiões vizinhas aumentará o nível de pobreza em uma região. A infraestrutura da extensão das estradas, infraestrutura de água potável, crescimento econômico, qualidade da educação e saúde têm influência significativa no nível de pobreza, embora a porcentagem de saneamento decente não tenha demonstrado afetar o efeito significativo sobre a pobreza. A conclusão é que o nível de pobreza nas províncias de Java Central e Yogyakarta tem uma distribuição desigual e um padrão espacial agrupado.

Palavras-chave: nível de pobreza, modelo espacial, análise de regressão espacial.

\section{INTRODUCTION}

One of the economic indicators to determine the level of prosperity of an area is by looking at the condition of poverty. So far, poverty is still an important problem that has not been solved in several regions throughout the world. This issue is stated in the Sustainable Development Goals (SDG), namely no poverty in the first point which shows that the question 
is the main priority that must be resolved (Liu et al., 2015). Poverty is a condition of economic incapacity to meet the population's average living standards in a region (Townsend, 1962).

Poverty reduction is an important question to point out because high poverty rates may cause many social problems (Pérez de la Fuente, 2016). The population included in the poor population group will not be able to fulfill their daily needs which may result in a shortage of food, clothing, and shelter. Furthermore, poverty if not addressed immediately may have an impact on more distant levels such as the problem of the quality of human life and health (Groce et al., 2011; Prayitno et al., 2019).

As a developing country, Indonesia has attempted to implement many poverty reduction programs, such as those found in the third Nawacita. As a result, in 2017 Statistics Indonesia (BPS) recorded a percentage of $10.12 \%$ of poor people in the country, a total of 26.58 million poor people, of which $52.4 \%$ of this population was in Java's territory. Java is the largest contributor to the PDB in Indonesia (more than 50\% of national Gross Domestic Product GDP) and has an increasing economic growth, however still presents high poverty rates (Badan Pusat Statistik, 2017). From 2009 to 2017, the largest percentage of poor people in Java was recorded alternating between Central Java and Yogyakarta Provinces. Although the poverty rate in the two provinces has decreased compared nationally or throughout Java is still relatively large, the data showed Central Java Province at 13.2\% and Yogyakarta at 13.1\% in 2016 (Badan Pusat Statistik, 2017). This value makes the two provinces ranked 12th and 13th in the highest percentage of poor people.

Poverty reduction is one of seven local government priorities in the Central Java Province Medium-Term Development Plan (RPJMD 2013-2018) which poverty reduction is the second priority (Central Java Province, 2014). Also, in the 2016 Special Region of Yogyakarta (DIY) Regional Development Work Plan (RKPD), the government of Yogyakarta is more prioritizing efforts to realize the welfare of the people and poverty reduction. The poverty rate in Yogyakarta which is still above the national average is a shared challenge, so poverty reduction is a very important part to be prioritized (Yogyakarta Province Government, 2016).

The availability of infrastructure in many regions of Java is considered quite sufficient when it is compared to other regions in Indonesia. There are some differences in infrastructure in Java Island with other regions in Indonesia, where the condition of infrastructure in Java is the best compared to others. Generally, the infrastructure in Java concerns more with maintaining and developing, while outside Java concerns more with creating new ones. This disparity cannot be distinguished from the fact that Java has been designed with a lot of infrastructures (Himawan \& Bagus, 2016). The availability of adequate infrastructure in Java, which includes Central Java province and Yogyakarta, should be able to overcome the existing poverty problems. According to World Bank (1994) infrastructure adequacy determines the success of a region in diversifying production, expanding trade, overcoming population growth, reducing poverty, or improving environmental conditions. Concerning poverty, access to infrastructure is a factor that can support the poor to get out of poverty condition. This is evidenced by the majority of the poor who have limited access to clean water and proper sanitation and limited mobility and communication which results in many problems in fulfilling their daily needs and obtaining employment opportunities. Thus, the influence of infrastructure on poverty levels in Central Java and Yogyakarta needs to be observed.

Besides the infrastructure, other important factors are used to determine the variables that affect poverty rates in Central Java and Yogyakarta. An important factor that determines the level of poverty in an area is the economic and social conditions. The success of economic activities in a region can be measured by its economic growth. According to Kuznet cited in Tambunan (2000), economic growth and poverty have a very strong correlation because in the early stages of the development process the poverty rate tends to increase, and at the end of the final stage of development the number of poor people gradually decrease. The problem of poverty is not only related to economic issues but is also related to many capabilities that must be owned by someone. In this case, one of them concerns the quality of existing human resources. According to Jeffrey Sachs cited by Ustama (2010), one 
mechanism in solving poverty is the development of human capital, especially in education and health.

The level of poverty in Central Java and Yogyakarta provinces from year to year does not show many differences when it is seen from the percentage of poor people. Moreover, the location of the two provinces borders directly. This indicates that poverty in a region is related to other adjacent areas. According to Tobler's first law that "Everything is related to everything else, but near things are more related than distant things." (Anselin, 2005). Related to this statement, there may be a spatial influence on poverty in many regions in the two provinces. Aklilu Zewdie et al. (2015) found that eradicating poverty should increase the education and working hours of the people in Java Island.

Several studies have been conducted previously related to the problem of poverty. Laswinia \& Chamid (2016) conducted a study on the modeling of poverty levels in 33 provinces in Indonesia in 2013. The results showed that the variables of economic growth rate, Human Development Index, and the environmental quality index had a significant effect on the percentage of the poor population. This study compared spatial and non-spatial models and obtained the best model of spatial error model (SEM). This shows the influence between regions in determining poverty levels. In line with this, Nugraha et al. (2020) found that infrastructure indirectly reduces income inequality.

Also, a study conducted by Humantito (2009) concerning the linkages between infrastructure and poverty in 26 provinces in Indonesia, showed that the infrastructure variables including road infrastructure, clean water, electricity, education, and health had a negative and significant effect on the percentage of poor people. A further finding in Thailand (Thongdara et al., 2012), shows that poor households have a typical relationship with large families, small farms, low crop yields, and low household incomes. The use of spatial autocorrelation and GIS by integrating data on wages, social, physical, and environmental factors contributes to poverty caused by land fertility, flood damage, pests, and lack of water. In spatial regression analysis, Prabandari et al. (2017) analyzed the connection between poverty and clean water usage. The results of the LISA analysis show that the adjacent areas are related to the regional level of poverty.

Furthermore, the research conducted by Kuncoro (2014), shows that the rates of economic growth, unemployment, and education when perceived from the Literacy Rate $(\mathrm{AMH})$ perspective has negative and significant effects on the poverty level in districts/cities in East Java Province. In line with the study, the results of Astuti (2015) showed that education is seen from the average school level; health is seen from the ratio of doctors available and had negative and significant effects on the number of poor people in Indonesia.

Based on the problems described, this study aims to determine the distribution of poverty levels in Central Java and Yogyakarta Provinces, to find out how the influence of infrastructure factors and socioeconomic conditions on poverty levels in Central Java and Yogyakarta Provinces taking into account the spatial aspects.

\section{METHODS}

\subsection{Data sources}

The data used in this study are secondary data from publications issued by the Central Bureau of Statistics. Secondary data to be used refers to the 2016 period with an observation unit of 40 districts/cities in Central Java and Yogyakarta Provinces.

The variable used in this study is the Percentage of Poor Population (POV) as the dependent variable. While the independent variable used refers to the variable economic infrastructure which includes the extension of good and medium roads every 10,000 inhabitants (ROAD), clean water supplied by clean water companies every 10,000 inhabitants (WATER), and the percentage of households that have proper sanitation (SANIT), socioeconomic variables covering the rate of economic growth (GROWTH), including the 
education index (EDUC), and the health index (HEALTH). All variables used are the data at the district/city level.

\subsection{Method of analysis}

The analytical method used in this study is the descriptive and inferential analysis. Descriptive analysis is used to give a general description of poverty in the provinces of Central Java and Yogyakarta using thematic charts and maps. In addition to describing poverty, it is also done by identifying the spatial autocorrelation of poverty levels using the Moran Scatterplot and the Local Indicators of Spatial Association (LISA) Map (Anselin, 1995). The spatial autocorrelation study in geographic contexts is represented by the degree of data dependence from two spatial (Anselin, 1988; Cliff \& Ord, 1973). LISA was used primarily to examine the association between a region and its surroundings (Anselin, 1993, 1995).

Several spatial correlation steps have been suggested to allow the evolution of spatial analysis from multiple perspectives to be explored (Zhao et al., 2017, 2019). However, the statistic from Moran's I is commonly used as a measure of the global spatial autocorrelation (Moran, 1948). It was first initiated by Moran (1948) then by Geary (1954), followed by Cliff \& Ord (1973). The Moran Scatterplot, first defined in Anselin (1993, 2005), shows a map with the $y$-axis of the original variable and x-axis. Whereas for the inferential analysis, spatial regression analysis is used to determine the effect of the independent variables on the level of poverty with spatial consideration based on the neighboring area which is contiguous (queen contiguity).

The stages of spatial regression analysis carried out in this study refer to the spatial regression decision process by Anselin (2005) as follows: 1) Identifying spatial dependencies and spatial heterogeneity using Moran's I statistic and Breusch-Pagan statistical tests on nonparticipatory models. If there are no spatial dependencies, the model used is the classic Ordinary least squares (OLS) model. If there are spatial dependencies but also spatial heterogeneity, the model used is Geographically weighted regression (GWR); 2) Conducting spatial linkage testing using the Lagrange Multiplier spatial lag (LM-lag) and Lagrange Multiplier spatial error (LM-error) test: a) If LM-lag and LM-error tests do not significant, the chosen model is a non-participatory or OLS regression model; b) If there is only one significant test, the chosen model is the significant model, it is the Spatial Autoregressive model (SAR) if the LM-lag test is significant and the Spatial error model if the LM-error test is significant; $c$ ) If the two tests are significant then the Robust LM lag and robust LM error tests are carried out, the model chosen is the more significant model of robust LM test; 3) To perform the testing assumptions; 4) Interpretation and analysis.

Based on the purpose of this study to determine the significant effect of the independent variables on poverty levels, the specifications of the general model of spatial regression equations in this study are as follows (Equation 1 and Equation 2):

$$
\begin{aligned}
& \text { POV }_{i}=\rho \sum_{i=1}^{40} w_{i j P O V}+\beta_{0}+\beta_{1} \text { ROAD }_{i}+\beta_{2} \text { WATER }_{i}+ \\
& \beta_{3} \text { SANIT }_{i}+\beta_{4} \text { GROWTH }_{i}+\beta_{5} E D U C_{i}+\beta_{6} \text { HEALTH }_{i}+\mu_{i} \\
& \mu_{i}=\lambda \sum_{j=1}^{40} w_{i j} \mu_{j}+\varepsilon_{i}
\end{aligned}
$$

Both were derived from Anselin (2005).

Where $\rho$ is the spatial autocorrelation lag coefficient, $\lambda$ is the spatial error autocorrelation coefficient and $w_{i j}$ is the spatial consideration matrix of $i$ and $j$ regions. From the model above there are several possible models that can be formed, they are: (1) Non-spatial model (OLS), if there is no spatial relationship ( $\rho=0$ and $\lambda=0)$; (2) Spatial lag model (SAR), if there is a spatial 
correlation between the dependent variable in poverty level $(\rho \neq 0, \lambda=0)$; (3) Spatial error model, if there are spatial linkages that occur in the error $(\rho=0, \lambda \neq 0)$.

\section{RESULTS AND DISCUSSION}

\subsection{The percentage distribution of poor population in Central Java and Yogyakarta Provinces}

Poverty is still a considerable problem in the Central Java and Yogyakarta Provinces. This poverty also needs attention and scrutiny from local governments in the two provinces. From year to year, the highest poverty level of Java Island alternates between Central Java and Yogyakarta. In 2009 Central Java the poverty rates were the highest in Java, while in the period 2010 to 2014 the highest poverty rate was in Yogyakarta, and then in the following year, Central Java became the highest (Figure 1).

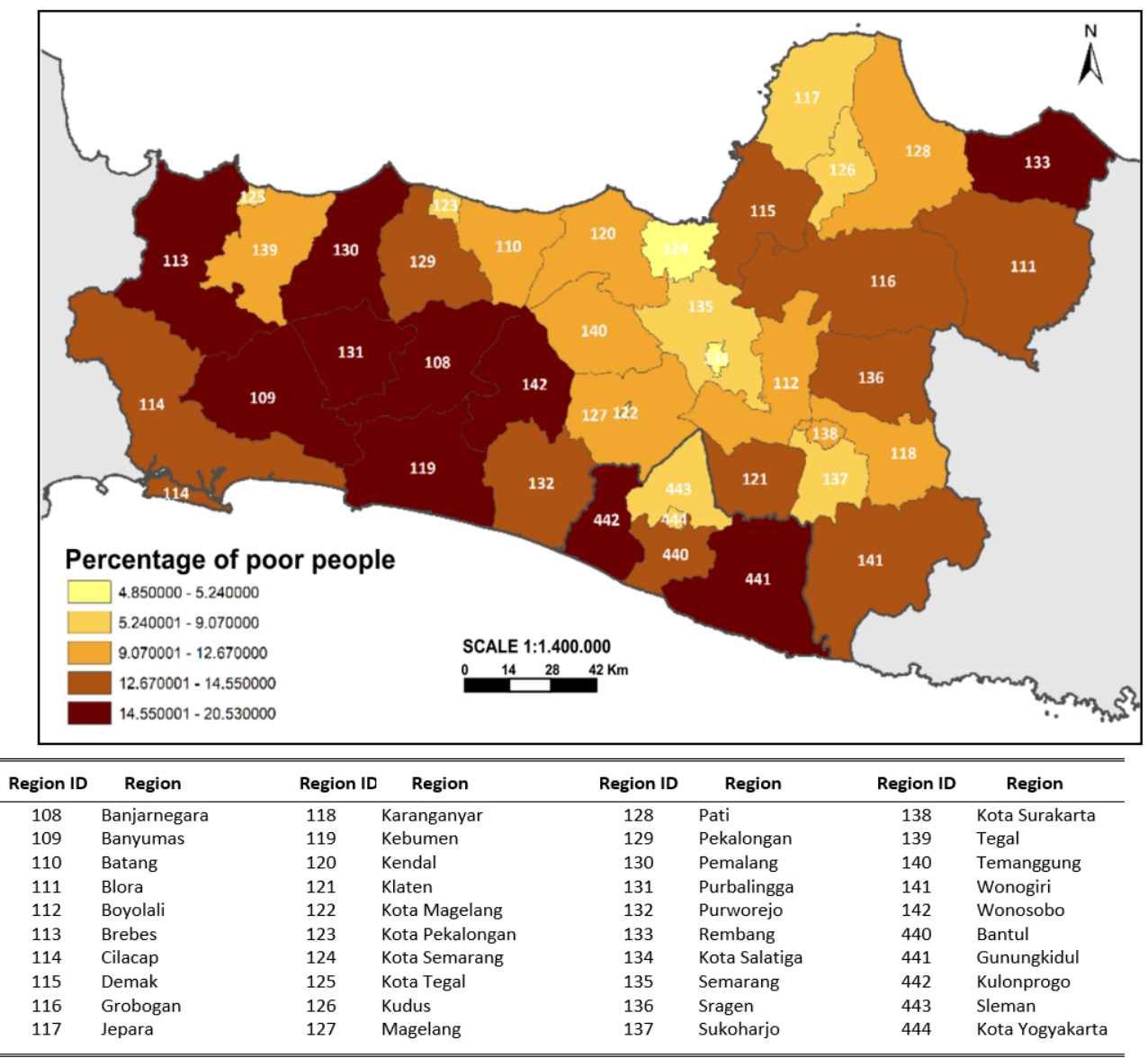

Figure 1. The percentage of poor people in Central Java and Yogyakarta provinces by the central bureau of statistics in 2016.

In 2016 the percentage of poor people in Central Java was 13.2\% and Yogyakarta was $13.1 \%$. If this number is converted into mental units, there will be 4,982 million poor people from the two provinces. The poverty level in Central Java and Yogyakarta has a considerable variation, in which the percentage of poor people between districts/cities in the two provinces varies. From Figure 2, it is possible to observe that there are 19 districts/cities that have a percentage of poor population greater than the average percentage of poor people in the two provinces. Wonosobo and Kulon Progo districts are regions that have the highest poverty rates of $20.5 \%$ and $20.3 \%$. Whereas the region with the lowest poverty rate is Semarang City, which is the capital of Central Java Province, with the percentage of poor population only 4.85\% (Central Bureau of Statistics, 2016). 


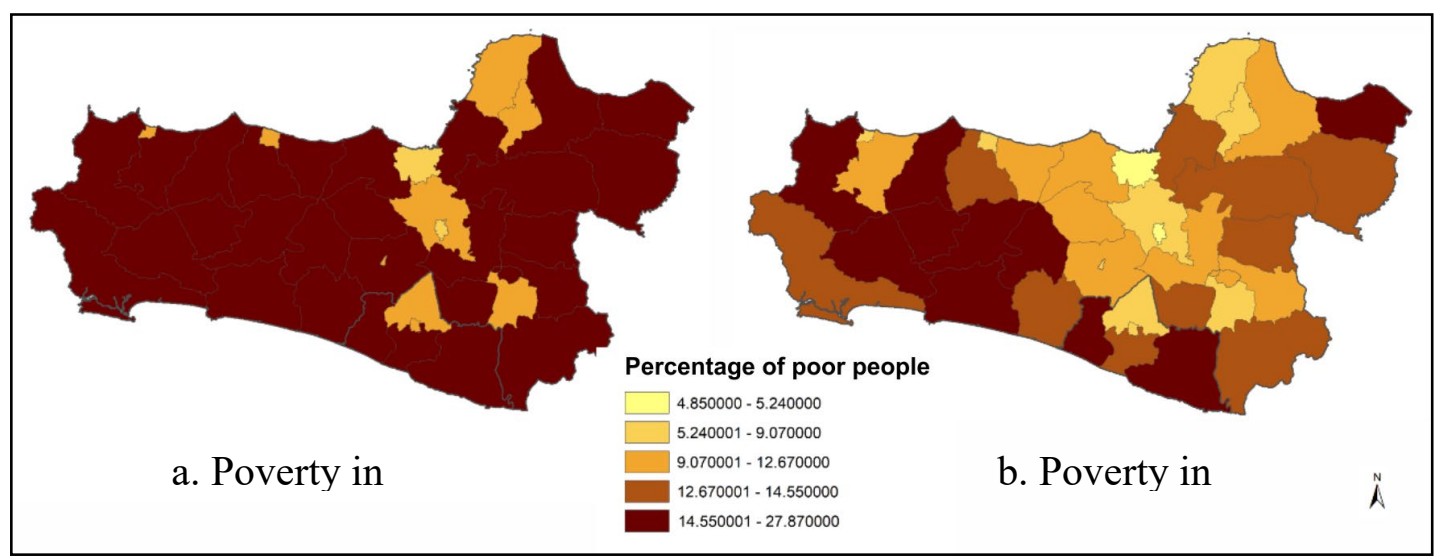

Figure 2. Distribution of poverty in Central Java and Yogyakarta provinces in 2009 (a) and 2016 (b) by the central statistics agency.

One of the problems that occurred in Central Java and Yogyakarta Provinces was that there is still inequality in poverty levels between regions. This can be seen in Figure 2 which presents poverty mapping per district/city in 2016. Based on Figure 2, it can be perceived that the poverty in the region has an irregular distribution and it seems to concentrate in a specified area. In the eastern and northern districts/cities, the poverty conditions are quite good, such as in Jepara, Kudus, Sukoharjo, Sleman, and in the cities of Semarang and Salatiga, where the districts/cities have the poverty percentage below $10 \%$. Meanwhile, the percentage of poor people in the regencies or cities in the west and south looks higher than in other regions. Some districts in the west and south have a percentage of poor people above 15\%, such as in Brebes, Banyumas, Pemalang, Purbalingga, Banjarnegara, Kebumen, Wonosobo, Kulon Progo, and Gunungkidul.

Compared with the poverty level in 2009 and 2016, there was a significant decline in poverty levels in the eastern and northern regions (Figure 2). This shows that from 2009 to 2016, there was a considerable reduction in poverty in districts around the region with low poverty levels, while the districts that far from areas with low poverty levels tended to decrease in poverty rates slowly. This it can be indicated that poverty has a connection with the surrounding region, where regions with low poverty levels influence and make the poverty rate in the surrounding area gradually become lower.

\subsection{The identification of inter-regional poverty level linkages}

The poverty level with uneven distribution and concentration in a particular area gives a little illustration of the linked existence between the level of poverty in a region and the surrounding area called spatial linkages. The level of poverty in a region is very likely to affect the level of poverty in other adjacent areas. This can occur because of the interaction between residents in adjacent areas, such as in terms of interaction in the economic and social fields. Thus, a region with high poverty rates may tend to have neighboring regions with high poverty rates.

The identification of spatial linkages between regions was carried out by using spatial data analysis through the Moran Scatterplot diagram and the Local Indicators of Spatial Association (LISA) map as follows (Anselin, 1995).

\subsection{Moran Scatterplot}

To analyze the spatial linkages, the aspects that need to be considered are spatial consideration matrices. In this research, the spatial consideration matrix, the queen contiguity is used because in the problem of poverty spatial linkages often occur due to the interaction between adjacent regions, which the adjacent region can be shown from the intersection of both sides and angles. The spatial relevancy is shown by the Moran Scatterplot in the poverty 
rate (Figure 3). The data used is standardized, so the units in the graph are presented in the standard deviation of the average. The horizontal axis shows the standardized poverty level for a district/city, while the vertical axis shows the standardization value of the poverty rate for the neighboring districts/cities (spatial lag of poverty) as defined in the spatial consideration matrix.

Anselin $(1993,1995)$ explained that the slope of the regression line (green line in Figure 3) in the Moran Scatterplot shows the value of Global Moran's Index. In Figure 3, the Global Moran's I of poverty rate is 0.202769 with a $p$-value of 0.0328 (rejecting the $\mathrm{HO}$ at the $5 \%$ significance level) showing that the distribution of poverty levels in all districts/cities has a clustered spatial pattern. Moran Scatterplot in Figure 3 shows the correlation between the standardized value of poverty variable in a region (X-axis) and the standardized value of average poverty in the neighbors called lagged poverty (Y-axis). Moran Scatterplot classifies the districts/cities into four quadrants. Quadrant I (high) and III (low-low) shows positive spatial autocorrelation (unidirectional) which indicates areas with poverty levels that are equal or comparable to their neighbors, while quadrant II (low-high) and IV (high-low) indicate negative spatial autocorrelation (opposite direction) which indicates areas with different levels of poverty than their neighbors.

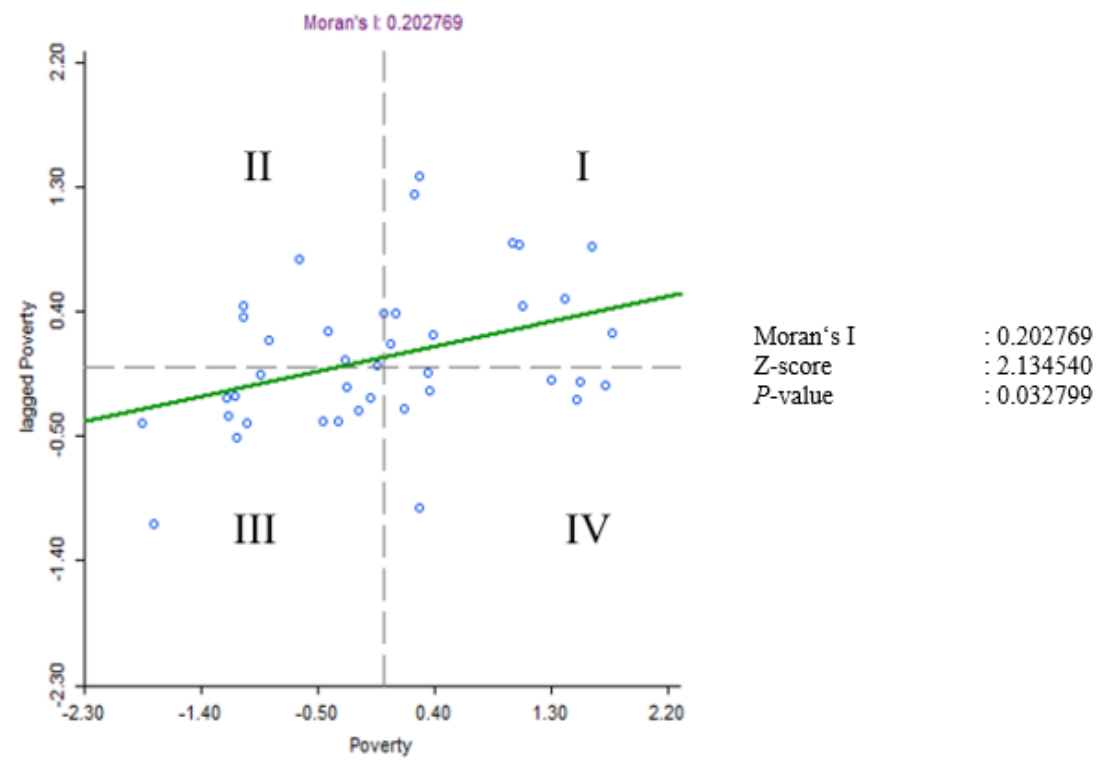

Figure 3. The percentage diagram of Moran Scatterplot of poor people in Central Java and Yogyakarta in 2016.

\subsection{The local indicators of spatial association (LISA) map}

The LISA map was introduced by Laswinia \& Chamid (2016) who visualized the grouping of local spatial associations into maps by using local Moran statistical tests to show a significant area that had local spatial autocorrelation (Anselin, 1995). By the significance level of $5 \%$, the district/city area that is significant has a spatial autocorrelation of poverty levels depicted in the LISA cluster map shown in Figure 4.

From Figure 4, it can be seen that 5 districts have significant poverty levels and will be equal to the level of poverty in their high-high area, including Banjarnegara, Banyumas, Cilacap, Kebumen, and Purworejo districts. Then there is one district/city that has a significant poverty rate and will be equal to the low-low poverty level, it is Semarang Regency. Besides, the districts/cities that have significant low poverty level that will be the same as their neighbors with high (low-high) poverty, it is Tegal Regency. Whereas the districts/cities that have a high poverty rate that may be the same as their neighbors with low (high-low) poverty that is Demak district. 


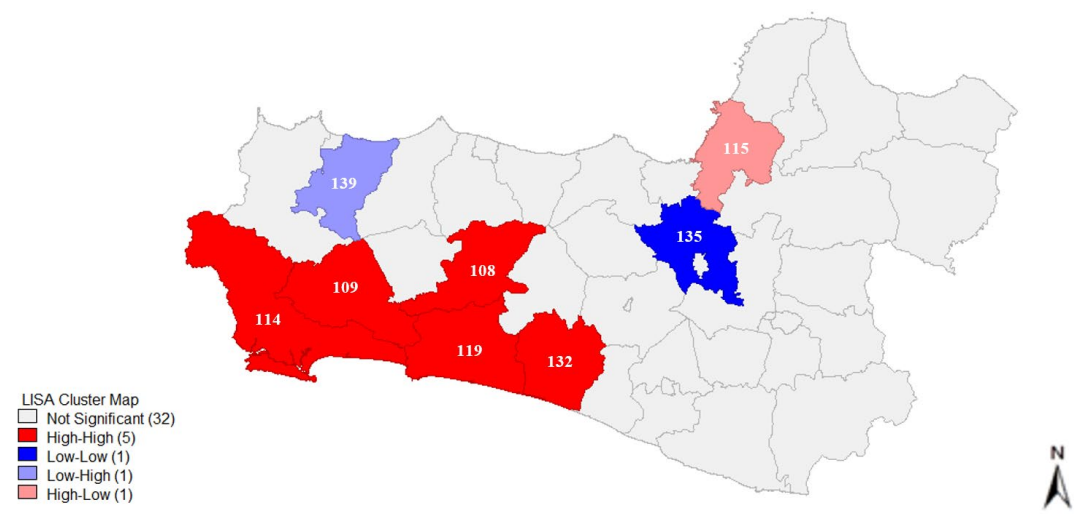

Figure 4. The local cluster indicators of spatial association maps of the poor people percentage in Central Java and Yogyakarta in 2016.

\subsection{The effect analysis of independent variables on the level of poverty in Central Java and Yogyakarta provinces by using spatial regression}

The first step in the formation of a spatial regression model is to identify the presence of spatial dependencies and heterogeneity in the non-spatial model. Moran's I (Table 1) shows significant results so that it can be concluded that there are spatial dependencies, which means that each district or city in Central Java and Yogyakarta Provinces that are close to each other have a close relationship. This relationship will later be explained in spatial regression modeling. Whereas the Breusch-Pagan test shows insignificant results so that it can be observed that there is no spatial heterogeneity, which means that each regency/city in Central Java and Yogyakarta Provinces shares one to another (variance in each location is the same) so global regression is able to use because it can explain the actual data phenomena. Next, the Lagrange Multiplier (LM spatial lag and LM spatial error) test to determine the accurate specification of the spatial model (Table 2).

Table 1. The test result of spatial effect

\begin{tabular}{cccc} 
Test & Mi/df & Value & p-value \\
\hline Moran's I (error) & 0.2777 & 3.3617 & 0.00077 \\
Breusch Pagan & 6 & 5.1235 & 0.52808 \\
\hline
\end{tabular}

Based on LM spatial lag test and LM spatial error (Table 2), it shows a significant result on the Lagrange Multiplier error meaning that the spatial error model is more appropriate to use. After the specification of the spatial model is obtained, the next step is to estimate the model parameters. The following are the results of the selected model parameter estimation, namely the spatial error model.

The parameter estimation results from the spatial error model (SEM) obtained variable extensions of road, clean water channeled, economic growth, education, and health have a significant effect on the dependent variable at the $5 \%$ significance level. However, the proper sanitation variable does not show a significant effect at the $5 \%$ significance level.

Based on the estimation of the spatial error model, it can be demonstrated in the equation as follows.

$$
\begin{aligned}
& \text { POV }_{i}=92.8298+0.4429 \text { ROAD }_{i}-0.5579 \text { WATER }_{i}+0.0101 \text { SANIT }_{i}- \\
& 0.2583 \text { GROWTH }_{i}-0.2988 \text { EDUC }_{i}-0.7459 \text { HEALTH }_{i}+0.5842 \sum_{j=1}^{40} w_{i j} \mu_{j}
\end{aligned}
$$


From the formed equation results in $R$-square value of 0.6424 indicates that the independent variables contained in the model can explain the variation in the percentage of poor people by $64.24 \%$, while the remaining $35.76 \%$ is explained by other variables outside the model.

The next step is to perform a normality test on the residual model formed with JarqueBera Test. Table 2 shows the results of the Jarque-Bera test that failed to reject HO ( $p$-value > 0.05), so it can be concluded that the residuals are normally distributed.

Table 2. The test result of Lagrange Multiplier and Robust LM

\begin{tabular}{cccc} 
Test & Df & Value & p-value \\
Lagrange Multiplier (Lag) & 1 & 0.6755 & 0.41113 \\
Lagrange Multiplier (Error) & 1 & 6.0923 & 0.01358 \\
\hline
\end{tabular}

A descriptive statistic with a standard deviation was calculated to determine the deviation of data from the variables used (Table 3).

Table 3. Descriptive statistics of poverty and socioeconomic conditions

\begin{tabular}{cccccc} 
Variable & N & Minimum & Maximum & Average & Std. Deviation \\
Poverty & 40 & 4.85 & 20.53 & 12.8898 & 4.33661 \\
Road & 40 & 2.739144 & 16.736402 & 6.544282 & 3.042330 \\
Water & 40 & 1.023090 & 8.966179 & 2.372314 & 1.382881 \\
Sanitation & 40 & 34.0 & 99.9 & 78.360 & 13.3286 \\
Growth & 40 & 2.421130 & 23.526673 & 5.605578 & 2.963842 \\
Education & 40 & 52.1500 & 84.7611 & 61.361250 & 8.078082 \\
Health & 40 & 74.4769 & 88.4000 & 83.871538 & 2.860180 \\
\hline
\end{tabular}

Then from multicollinearity detection (Table 4) shows that multicollinearity does not occur in the independent variable discovered from the absence of VIF (Variance Inflation Factor) that is greater than 10 .

Table 4. Multicollinearity detection result

\begin{tabular}{ccccc} 
Variable & Coefficient & Std. Error & Z-value & p-value \\
Intercept & 92.8298 & 16.6049 & 5.59052 & $0.00000^{*}$ \\
Spatial Error $(\lambda)$ & 0.584204 & 0.144391 & 4.04598 & $0.00005^{*}$ \\
Road & 0.442999 & 0.170416 & 2.59951 & $0.00934^{*}$ \\
Water & -0.557944 & 0.281978 & -1.97868 & $0.04785^{*}$ \\
Sanitation & 0.0100556 & 0.039099 & 0.257177 & 0.79704 \\
Growth & -0.258277 & 0.13116 & -1.96918 & $0.04893^{*}$ \\
Education & -0.29887 & 0.076399 & -3.91194 & $0.00009^{*}$ \\
Health & -0.745931 & 0.219851 & -3.3929 & $0.00069^{*}$ \\
& R-Square & & \multicolumn{2}{c}{0.642426}
\end{tabular}

Note: *the significances on real level $5 \%$

Based on Table 4, it can be seen that spatial error $(\lambda)$ is significant, which means there is spatial relevance in error, so it can be stated that the poverty level in an area is influenced by variables outside origin (errors) from neighboring regions. The spatial error $(\lambda)$ coefficient is 0.5842 which shows the increase of 1 point in the spatial error of neighboring districts/cities will increase poverty by about $0.59 \%$. For example, Kudus Regency which has four neighbors, 
namely Jepara, Pati, Grobogan, and Demak Regencies, the poverty model equation in Kudus Regency can be detailed as follows:

$\widehat{P O V}_{K d s}=92.8298+0.4429$ ROAD $_{K d s}-0.5579$ WATER $_{K d s}+0.0101$ SANIT $_{K d s}-0.2583$ GROWTH $_{K d s}$
-0.2988 EDUC $_{K d s}-0.7459$ HEALTH $_{K d s}+0.5842\left(\frac{1}{4} \mu_{\text {Jepara }}+\frac{1}{4} \mu_{\text {Pati }}+\frac{1}{4} \mu_{\text {Grobogan }}+\frac{1}{4} \mu_{\text {Demak }}\right)$

This result is in line with the research of Laswinia \& Chamid (2016) which showed that there are spatial dependencies in error in the pattern of the relationship of the percentage of poor people with environmental, economic, and social factors. Besides, Higazi et al. (2013) in their research on the application of spatial regression to poverty also obtained error spatial dependencies.

The extension of the road variable (ROAD) has a positive and significant influence on the level of poverty. This means that an increase in road extension of $1 \mathrm{~km}$ per 10,000 residents may increase the percentage of poor population by $0.443 \%$. This positive coefficient shows the result that in contrast to the existing literature. This positive influence indicates a backwash effect. The backwash effect occurs if the region that is experiencing economic growth attracts other regional resources around it so that there are differences in economic growth between regions which are the destination of the transfer of resources with the abandoned area (Azzainuri, 2014). The addition of road access may facilitate the transfer of resources from the area left to the destination area, causing the abandoned area to undergo a lack of resources that allows for inequality between regions (Malik, 2017) since the high level of inequality between countries is closely related to the high percentage of poor people. According to Kuncoro (2014) stated that poverty arises because of the inequality of patterns of ownership of resources that lead to unequal income distribution.

The variable of clean water distributed by companies has a negative and significant effect on poverty levels. The coefficient value produced shows an increase of 1 million $\mathrm{m}^{3}$ the amount of clean water distributed per 10,000 residents may reduce the percentage of poor population by $0.558 \%$ by assuming ceteris paribus. This result is in line with Humantito's (2009) research who stated the availability of drinking water infrastructure is reflected in capacity production by companies has a negative and significant effect on poverty levels which shows that the availability of clean water ready for consumption can reduce the percentage of poor people.

The percentage variable of households with proper sanitation has a $p$-value of 0.79704 indicating the results of failing to reject $\mathrm{HO}$ because the $p$-value is more than $\alpha(0.05)$, it means that with a significance level of $5 \%$ it can be said that the proper sanitation variable has no significant effect to the percentage of poor people in Central Java and Yogyakarta. This result is in line with Humantito's (2009) research that showed that sanitation has no significant effect on poverty in East Java. This is affirmed because almost all communities have used private toilet facilities with good infrastructure conditions.

The variable of economic growth rates has a significant negative effect on poverty levels. The increasing rate of economic growth by $1 \%$ may reduce the percentage of poor people by $0.258 \%$. This is in line with the research of Laswinia \& Chamid (2016) which the research shows that the increasing rate of economic growth can reduce poverty. The higher rate of economic growth of a province indicates that the welfare of the community increases so that the percentage of poverty can be reduced.

The educational variable has negative and a significant effect on the percentage of poverty. The increasing of the educational index by 1 point may reduce the percentage of the poor population by about $0.299 \%$. The average education based on Table 3 is 61.36 with a standard deviation of 8.07. According to Simmons' statement, if a region or country wants to save itself from the epidemic of poverty, the solution is to increase the level of education. In eradicating poverty, one way is to improve education (Arka \& Wirawan, 2015). 
The health variable has negative and significant effect on the percentage of poverty. A very small $p$-value indicates a considerable level of trust that the health variable harms the percentage of poverty. The coefficient value produced shows that an increase in the health index by 1 point may reduce the percentage of poor population by about $0.746 \%$ with the assumption that other variables are constant. This result is similar to Astuti's (2015) research that the public health level measured through life expectancy has negative and significant effects facing poverty.

\section{CONCLUSIONS}

The conclusions of this study are the level of poverty in the provinces of Central Java and Yogyakarta has an uneven distribution and a clustered spatial pattern. The western and southern districts/cities tend to have a high level of poverty, while the poverty conditions in the districts and cities in the eastern and northern tend to be better. The variables of the amount of clean water distributed the rate of economic growth; the education index and the health index have negative and significant effects on poverty levels in Central Java and Yogyakarta Provinces. The variable extension of the road has positives and significant effects on the level of poverty; while the variable percentage of households with proper sanitation does not have a significant effect on poverty levels. Also, there are spatial linkages that may result in errors which the increase of other variables outside the model (error) in neighboring regions may increase the level of poverty in a region.

Some suggestions based on results and discussion and conclusions can be produced as follows: 1) The effort to accelerate poverty reduction requires cooperation between adjacent (neighboring) regions because the poverty level of a region is related to the surrounding area; 2) Increasing the public access to clean water by developing clean water distribution undertaken by companies. In addition to overcoming the problem of poverty it is necessary to prioritize the programs and policies that improve the education and health quality, and economic growth; 3) For further research, it can add other infrastructure variables so that they can more reflect the actual state of infrastructure and clarify the effect on poverty levels.

\section{REFERENCES}

Aklilu Zewdie, M., Aidi, M., \& Sartono, B. (2015). Spatial econometric model of poverty in Java Island. American Journal of Theoretical and Applied Statistics, 4(6), 420. http://dx.doi.org/10.11648/j.ajtas.20150406.11

Anselin, L. (1988). Spatial econometrics: methods and models. Dordrecht: Springer. http://dx.doi.org/10.1007/978-94-015-7799-1.

Anselin, L. (1993). The Moran scatterplot as an ESDA tool to assess local instability in spatial association. Morgantown, WV: Regional Research Institute, West Virginia, University Morgantown.

Anselin, L. (1995). Local Indicators of Spatial Association - LISA. Geographical Analysis, 27(2), 93-115. http://dx.doi.org/10.1111/j.1538-4632.1995.tb00338.x

Anselin, L. (2005). Exploring spatial data with GeoDa: a workbook. Urbana: Center for Spatially Integrated Social Science, University of Illinois.

Arka, S., \& Wirawan, I. M. T. (2015). Analisis Pengaruh Pendidikan, PBRB Per Kapita dan Tingkat Pengangguran Terhadap Jumlah Penduduk Miskin Provinsi Bali. EP Unud, 4(5), 546-560. Retrieved in 2013, August 15, from https://ojs.unud.ac.id/index.php/eep/article/view/12339/9117

Astuti, R. R. (2015). Analisis Pengaruh Jumlah Penduduk, Pertumbuhan Ekonomi, Pendidikan dan Kesehatan terhadap Jumlah Penduduk Miskin di Indonesia tahun 2004-2012. Yogyakarta: Universitas Negeri Yogyakarta.

Azzainuri, M. D. (2014). Determinan Ketimpangan Pembangunan Ekonomi Antarprovinsi di Indonesia Tahun 2006-2012. Indonesia: Sekolah Tinggi Ilmu Statistik.

Badan Pusat Statistik - BPS. (2017). Multiyears data (Stattistic). Indonesia.

Central Bureau of Statistics. (2016). Statistik Indonesia 2016 [Statistic of Indonesia 2016]. Indonesia. 
Central Java Province (2014). Rencana Pembangunan Jangka Menengah Daerah (RPJMD) Provinsi Jawa Tengah Tahun 2013-2018. Badan Perencanaan Pembangunan Daerah.

Cliff, A. D., \& Ord, J. K. (1973). Spatial autocorrelation. London: Pion.

Geary, R. C. (1954). The contiguity ratio and statistical mapping. The Incorporated Statistician, 5(3), $115-$ 146. http://dx.doi.org/10.2307/2986645

Groce, N., Kembhavi, G., Wirz, S., Lang, R., Trani, J.-F., \& Kett, M. (2011). Poverty and disability: a critical review of the literature in low and middle-income countries. SSRN. http://dx.doi.org/10.2139/ssrn.3398431

Higazi, S. F., Abdel-H., D., \& Al-Oulfi, S. A. (2013). Application of spatial regression models to income poverty ratios in middle delta contiguous Counties in Egypt. Journal Statistic Operation Research, 9(1), 93-110.

Himawan, A., \& Bagus, S. (2016, October). Ini Beda Proyek Infrastruktur di Jawa dan Luar Jawa. Suara.com.

Humantito, I. J. (2009). Analisis Keterkaitan Ketersediaan Infrastruktur terhadap Kemiskinan di Indonesia. Indonesia: Universitas Indonesia.

Kuncoro, S. (2014). Analisis Pengaruh Pertumbuhan Ekonomi, Tingkat Pengangguran dan Pendidikan Terhadap Tingkat Kemiskinan di Provinsi Jawa Timur Tahun 2009-2011. Indonesia: Universitas Muhammadiyah Surakarta.

Laswinia, V. D., \& Chamid, M. S. (2016). Analisis Pola Hubungan Persentase Penduduk dan Sosial di Indonesia Menggunakan Regresi Spasial. Jurnal Sains Dan Seni ITS, 5(2), 1-6. http://dx.doi.org/10.5152/jaem.2014.16769

Liu, Q. Q., Yu, M., \& Wang, X. L. (2015). Poverty reduction within the framework of SDGs and Post-2015 Development Agenda. Advances in Climate Change Research, 6(1), 67-73. http://dx.doi.org/10.1016/j.accre.2015.09.004

Malik, H. (2017). Analisis Determinan Ketimpangan Pembangunan Ekonomi menurut Kawasan di Indonesia Tahun 2007-2015. Sekolah Tinggi Ilmu Statistik.

Moran, P. A. P. (1948). The Interpretation of Statistical Maps. Journal of the Royal Statistical Society. Series B. Methodological, 10(2), 243-251. http://dx.doi.org/10.1111/j.2517-6161.1948.tb00012.x

Nugraha, A. T., Prayitno, G., Situmorang, M. E., \& Nasution, A. (2020). The role of infrastructure in economic growth and income inequality in Indonesia. Economia e Sociologia, 13(1), 102-115. http://dx.doi.org/10.14254/2071-789X.2020/13-1/7

Pérez de la Fuente, B. (2016). Economic growth and poverty reduction in a rapidly changing World. European Economy. Economic Brief, 19(October), 2-17. http://dx.doi.org/10.2765/730208

Prabandari, A., Ari, I. R., \& Hariyani, S. (2017). Pemodelan Spasial Water Poverty Index dengan Infrastruktur dan Kondisi Sosial Pada Kelurahan Cemorokandang Kota Malang. Brawijya University.

Prayitno, G., Sari, N., \& Putri, I. K. (2019). Social capital in poverty alleviation through Pro-Poor Tourism concept in Slum Area (Case Study: Kelurahan Jodipan, Malang City). International Journal of GEOMATE, 16(55), 131-137. http://dx.doi.org/10.21660/2019.55.37152

Tambunan, T. (2000). Perekonomian Indonesia: teori, temuan, dan empiris. Indonesia: Ghalia.

Thongdara, R., Samarakoon, L., Shrestha, R. P., \& Ranamukhaarachchi, S. L. (2012). Using GIS and spatial statistics to target poverty and improve poverty alleviation programs: a case study in Northeast Thailand. Applied Spatial Analysis and Policy, 5(2), 157-182. http://dx.doi.org/10.1007/s12061-0119066-8

Townsend, P. (1962). The meaning of poverty. The British Journal of Sociology, 13(3), 210-227. http://dx.doi.org/10.2307/587266

Ustama, D. D. (2010). Peranan Pendidikan Dalam Pengentasan Kemiskinan. Dialogue, 6(1), 1-12.

World Bank. (1994). World Development report 1994 infrastructure for development. Oxford: Oxford University Press.

Yogyakarta Province Government. (2016). Rencana Kerja Pembangunan Daerah Daerah Istimewa Yogyakarta (RKPD DIY).

Zhao, R., Tian, Y., Lei, A., Boadu, F., \& Ren, Z. (2019). The effect of local government debt on regional economic growth in China: a nonlinear relationship approach. Sustainability, 11(11), 1-22. http://dx.doi.org/10.3390/su11113065 
Zhao, X., Zheng, Y., Huang, X., Kwan, M. P., \& Zhao, Y. (2017). The effect of urbanization and farmland transfer on the spatial patterns of non-grain farmland in China. Sustainability, 9(8), 1438. http://dx.doi.org/10.3390/su9081438

Received: January 21, 2020

Accepted: February 17, 2021

JEL Classification: $\mathrm{O} 1, \mathrm{O}$, $\mathrm{HO}$ 